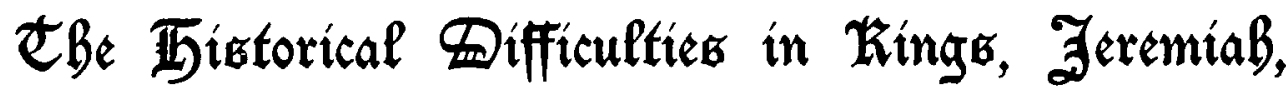 and Danike.
}

By the Rev. George Douglas, Edinburgh.

ThE Books of Kings, Jeremiah, and Daniel have the appearance of being inconsistent in the matter of dates. In the opening verses of Daniel it is said that " in the third year of the reign of Jehoiakim king of Judah came Nebuchadnezzar king of Babylon unto Jerusalem, and besieged it, and the Lord gave Jehoiakim king of Judah into his hand." In Jeremiah, on the other hand, it is always the fourth year of Jehoiakim that is Nebuchadnezzar's first $;^{1}$ and Jeremiah prophesying in Jehoiakim's fourth year threatens an invasion on the part of Nebuchadnezzar, in language which would make one suppose that the Babylonian king had never been in the Holy Land up to that time. $^{2} \quad$ Elsewhere in the writings of the same prophet, Nebuchadnezzar is referred to as smiting the army of Pharaoh-Necho in the battle of Carchemish, also in the fourth year of Jehoiakim $;^{3}$ and what we know from history makes it next to impossible that he can have been at Jerusalem before that battle. It would appear that Nebuchadnezzar marched westward from Babylon in the last year of his father's reign, with an army just released from the siege and destruction of Nineveh, to attack the countries which owned subjection to the king of Egypt; that he first fell on the Egyptians themselves, overthrowing them; that, driving them before him, he then dashed down through Palestine, and came to Jerusalem, "and besieged it, and that the Lord gave Jehoiakim king of Judah into his hand"; but that, somewhere in his career of conquest, he heard of his father's death, and had to hurry back to Babylon to secure the throne. The dates of Jeremiah, and the course of history taken together, would seem to make it impossible that Nebuchadnezzar could have been at Jerusalem before Jehoiakim's fourth year. It has been common, therefore, to regard the first verse of Daniel as being in error.

De Wette wrote: "It is obviously false that Jehoiakim was carried thither at that date," and "the false statement in Dan. i. I renders the historical
1 Jer. xxv. $x$.
2 Jer. $x x v$.
${ }^{3}$ Jer. xlvi.

existence of Daniel exceedingly doubtful." 4 Many writers of the present day are of the same mind. Wellhausen, after his manner, is more sweeping: he regards the whole dates of the period as being adapted, and finishes a paragraph on the subject thus :-“" . . Josiah, Jehoahaz, Jehoiakim, Jehoiachin, $79 \frac{1}{4}$. Let him believe who can that it is a mere chance that the figures $4 \mathrm{I}+8 \mathrm{I}+38$ make up exactly $40+80+40 . " 5$ Robertson Smith, equally assuming error in the Scripture figures, corrects the length of Jehoiakim's reign; he says, "Hence we must conclude that the first year of Nebuchadnezzar-that is, the first year which began in his reign-was really the fifth of Jehoiakim, and that the latter reigned not eleven [as stated in the Bible], but twelve years, ${ }^{\circ}$ a conclusion which is referred to and endorsed by Cheyne. ${ }^{7}$

The apparently contradictory dates, however, are not without their defenders. Keil, e.g.,- - and many agree with him,-reconciles them by supposing that Nebuchadnezzar set out from Babylon in the third year of Jehoiakim, and appeared before Jerusalem in the fourth, and reading this meaning into the first verse of Daniel he supports it by asserting that while 콘 generally signifies "came," it also means "went" - a reconciliation which, taken altogether, is, I fear, not likely to have a reassuring effect upon those who waver on the general subject of the Book of Daniel. Pusey has a different solution of the difficulty. According to

4 Introduction to the Old Testament, vol. ii. pp. 484,486 . Observe it is not said in the Bible that Jehoiakim was carried to Babylon. The words are: "The Lord gave Jehoiakim king of Judah into his hand, with part of the vessels of the house of God ; and he carried thim into the land of Shinar to the house of his god." According to 2 Chron. xxxvi. 6, 7 : "Against him came up Nebuchadnezzar king of Babylon, and bound him in fetters to carry him to Babylon. Nebuchadnezzar also carried of the vessels of the house of the Lord to Babylon, and put them in his temple at Babylon." There is reason to believe that his purpose of carrying Jehoiakim to Babylon was never executed.

S Prolegomena to the History of Israel, pp. 272, 273.

${ }^{6}$ Prophets of Israel, p. 415.

7 Pulpit Commentary on Jeremiah, p. 18.

${ }^{8}$ Commentary on Daniel, chap. i. $\mathrm{I}$. 
him Jerusalem was besieged and Jehoiakim taken in the third year of that king, as stated in the Bible; but he maintains that Nebuchadnezzar did not go to Carchemish till the following year, and he holds that in the absence of fuller information we must simply accept these facts. ${ }^{1}$ Unfortunately, our information is much too full to allow us to believe that they are facts. Carchemish lies on the road from Babylon to Jerusalem, not quite half way; and, apart from other objections, we cannot without a definite and authoritative statement believe that a general like Nebuchadnezzar brought his army past that fortress, held as it was by the Egyptians, and left the Egyptian forces free to fall upon his capital. Whatever reading is given to the history, the nature of the case appears to demand that the battle of Carchemish shall precede the siege of Jerusalem.

Reconciliations like the foregoing might well make belief in the accuracy of the Scripture dates hopeless. But in the light of the tablets which have been brought from Nineveh and Babylon within the present generation, all difficulty vanishes. There has neither to be straining of the meaning of words nor twisting of history. It simply turns out that the Jews and the Babylonians had different modes of reckoning time. The Jews, as we know, computed a king's reign from the day of his accession to the day of his death, and they included every year in which any part of the reign lay. If, e.g., he began when one month of the year had yet to run, and went on through the whole of another year, and continued on the throne only one month of a third year, they said he reigned three years, although he had been king for only fourteen months. But now the Inscriptions tell us that the Babylonians did not reckon so. According to their general practice, they would not, in the supposed case, have counted that month of the first year to the new king at all ; it would have been given to his predecessor. The first year of the new king would have begun at the New Year's Day, after he came to the throne. The following year, however, would have been counted as a whole year to him, although of it he had only been a month in office. Whoever was on the throne when the year came in, to him it was reckoned, whether he saw it to its close or not. If they had to speak of the initial year with reference to the new king, their practice was to ${ }^{1}$ Lectures on Danicl, p. 399 sqq. call it not his "first year," but the "year of his accession," or the "year he began to reign," or simply the "year of his reign," his so-called "first year" taking date from the New Year's Day following. ${ }^{2}$ Occasionally, it is said, the initial year of the reign was called the "first year." The Babylonians, as became an astronomical people, had this advantage, that when they wished to compute a long period, they had merely to sum up the reigns of which it was composed; they were not troubled, like the Jews, with the last year of one reign overlapping the first of another. If, then, as was the case, Pharaoh-Necho set Jehoiakim upon the throne of Judah in 608 B.c., and Nebuchadnezzar made his first westward march in 605, overthrowing the Egyptians at Carchemish, besieging Jerusalem, and taking Jehoiakim, and hastening home through the desert the same year, Jeremiah and other writers using the Jewish method of computation would say that this was done in the fourth year of Jehoiakim; whereas, in the Book of Daniel, if it was written in Babylon, the time would be called the third year. In each case the writer would have no option; had he used other language, he would have been misunderstood. The portion of time which elapsed from Jehoiakim's ascending the throne till the last day of the year was called in Palestine the "first year" of his reign, and in Babylon the "accession year," or the "year of his reign," the full year which began on the succeeding New Year's Day being called by the Palestinian writer the "second year," and by the Babylonian the "first." What the Book of Jeremiah, therefore, according to Jewish practice, properly called the fourth year of Jehoiakim, the Book of Daniel with equal propriety, after the Babylonian manner, called the third, and the passages cited instead of being contradictory are confirmatory of each other.

2. Another difficulty has been found in the time when Daniel is said to have stood before the king. The statements of the Book of Daniel are these: (i. 5) He and his companions were to be "nourished three years, that at the end thereof they might stand before the king;" (i. I 8 ) "at the end of the days which the king had appointed for bringing them in, the prince of the eunuchs brought them in before Nebuchadnezzar ;" and lastly, (ii. I) "in the second year of the reign of Nebuchadnezzar, Nebuchad-

* See George Smith's Assyrian Discozeries, p. $3 \mathrm{S6}$; and his Assyrian Canon, p. $2 \mathrm{I}$. 
nezzar dreamed dreams," and Daniel was brought in to interpret. It has been a commonplace with critics that the "three years" and the "second year" of these passages make a manifest blunder between them, and that this is another evidence of the untrustworthy, if not the unhistorical, character of the book. Ingenious interpretations, on the other hand,--more ingenious than convincing, have been devised to show how Daniel could be brought to Babylon, be nourished three years, and still be only in the second year of Nebuchadnezzar's reign. As before, the difficulty is cleared away by the tablets. They show not only how at the end of three years Daniel might be in the second year of the reign, but how he could not be in any other. Of course, we understand in any case that when an Oriental says "at the end of three years," he does not mean "at the end of three times $3^{6} 5$ days." When he says that Jesus was three days and three nights in the heart of the earth, he does not mean three times twenty-four hours. As Nebuchadnezzar, therefore, with his small band of select captives came home in 605 B.C., and as Daniel's training would begin at once, it must have ended in 603 . It could not go beyond that time. Had it once crossed over the line into 602, it would have found itself in a fourth year. And now comes in the teaching of the tablets. Since Nebuchadnezzar ascended the throne in 605, his "first year" according to the Babylonian method of counting - the method of the Book of Daniel - was 604 , and his "second year" was 603 , the year in which Daniel's training ended. Again, the socalled "blunder" turns out to be a simple and accurate statement of fact.

3. Daniel, as we have seen, was included among the captives of Nebuchadnezzar's first raid, which occurred in what Jeremiah and the other Jews of Palestine called the first year of Nebuchadnezzar and fourth of Jehoiakim. The next captivity, which took place seven years later, swept off another prophet, Ezekiel; that was in the eighth year of Nebuchadnezzar and eleventh of Jehoiakim, or, as we should rather say, in the eighth of Nebuchadnezzar and the reign of Jehoiachin, for Jehoiachin's short reign of three months or more came in to complete Jehoiakim's eleventh year, and it was at the end of Jehoiachin's time that the captivity was made, Ezekiel and the young king being taken off together. After the New Year came in, Nebuchadnezzar set Zedekiah upon the
Jewish throne, and in Zedekiah's eleventh year he also was carried away, Jerusalem being destroyed at the same time; that was in the nineteenth year of Nebuchadnezzar. There were thus captivities in Nebuchadnezzar's first, eighth, and nineteenth years. But when we turn to the closing verses of 2 Kings and Jeremiah, we find these last called not the eighth and nineteenth, but the seventh and eighteenth. As before, on the one hand, these have been called palpable contradictions or indications of untrustworthiness in dates; and, on the other, ingenious theories have been devised to make them agree. A reading adopted by Ewald, Kuenen, ${ }^{1}$ and many others, inserts a Yod before " 7 th," making it " I 7 th." Others have multiplied the captivities, making one in the first year of Nebuchadnezzar, another in the seventh, another in the eighth, another in the eighteenth, another in the nineteenth-not to speak of the one in the twenty-third, a period of which we are still in ignorance.

It will have been surmised by the reader, according to the principle of the tablets, that the number which is given to the year will depend upon the local source of the writing. WV do not know who wrote the Books of Kings. They bear no author's name. But they appear to have been written in Judah before the Exile. ${ }^{2}$ The Book of Jeremiah, for our present purpose, is of the same place and time. But in the last chapter of 2 Kings and the last of Jeremiah-which are to a large extent one and the same-the closing verses are evidently of a later date than either of the books. They relate what occurred in Babylon many years after Jerusalem was laid in ruins and the Jewish state destroyed; and for that and other reasons, they are looked on as coming from a Babylonian source. We need not discuss how much of the chapters belongs to the later date. Suffice it to notice that the last four verses of Kings and the last seven of Jeremiah must be so regarded. And that observed, the dates are plain. The whole of the passages which place the captivities in the eighth and nineteenth years of Nebuchadnezzar belong to the writings which issue from Judah before the Exile and use the Jewish reckoning, while those which speak of the seventh and eighteenth years are of Babylon and employ the Babylonian computation.

1 Religion of Isracl, vol. ii. p. 175.

a See Driver's Introduction to the Litcralure of the Old Tistament, and ed., p. 188. 
The eighth and nineteenth regnal years, Jewish style, are the seventh and eighteenth Babylonian; and once more, out of the apparent inconsistency we get a real confirmation.

4. The most remarkable coincidence has yet to be considered. It is one in which the statements of Scripture comc into contact with the writings of Berosus and Ptolemy, and after appearing to differ from them and be inconsistent with each other, turn out to harmonise among themselves and agree with the writings of those authors.

Berosus, a Chaldæan, who is known to us by some fragments preserved in the works of other writers, tclls us in extracts which are quoted by Josephus $^{1}$ that Nebuchadnezzar heard of his father's death when he was on his first western campaign, and hastened home to secure the crown; and he goes on to say that he reigned forty-three years, and was succeeded by his son Evil-Merodach. Let us now turn to the Bible. In 2 Kings xxv. 27, it is said that Evil-Merodach began to reign in the thirty-seventh year of Jehoiachin's captivity. We should therefore infer that Nebuchadnezzar died, or, to put it otherwise, that Nebuchadnezzar's fortythird year was in the thirty-seventh of Jehoinchin's captivity. Keeping these numbers in mind, let us start anew from another set of passages. The first year of Nebuchadnezzar was Jehoiakim's fourth, ${ }^{2}$ the eighth was Jehoiakim's eleventh, ${ }^{3}$ which again was the year of the short reign and deportation of Jehoiachin; and if we add thirty-six years to the last date, we see that it would take a forty-fourth year of Nebuchadnezzar to coincide with the thirtyseventh of Jehoiachin's captivity. But according to the previous passage it was the forty-third, not the forty - fourth, of Nebuchadnezzar which coincided with that thirty-seventh. It would appear, therefore, either that Berosus is wrong who says Nebuchadnezzar reigned only forty-three years, or that the passage in the end of 2 Kings is wrong which says Evil-Merodach began to reign in the thirty-seventh of Jehoiachin's captivity, or that those other passages are wrong which require a forty-fourth year of Nebuchadnezzar to coincide with Jehoiachin's thirty-seventh. When, however, we remember that Berosus and the author of the last verses of 2 Kings, who write from a Babylonian

\footnotetext{
1 Josephus, Antig. x. chap. I I. sec. I ; $A$ f. i. I9, 20.

2 Jer. xxv. I.

32 Kings xxiii. $3^{6}$, xxiv, $8,12$.
}

point of view, call the year in which a king begins to reign, not his "first," but his " accession " year, and count his "first" year from the next New Year's Day, and that Jeremiah and the author of the earlier passages of 2 Kings reckon after the Jewish method, calling the year in which a king begins to reign his "first," we discover that all the four writers are agreed, Nebuchadnezzar reigning forty-four years according to the Jewish way of counting, and forty-three according to the BabyIonian, and the thirty-seventh year of Jehoiachin s captivity coinciding in either case with the last of Nebuchadnezzar's reign.

The other author to be compared is Ptolemy. He was a geographer and astronomer of Alexandria in the second century A.D., and drew up a list of Babylonian and other kings, showing the years in which each reigned. As he always makes the first year of a king's reign not coincident with the last of his predecessor, but a year after it, we see that he must have adopted the Babylonish numbers. With them he makes Nebuchadnezzar reign fortythree years, confirming the Bible and Berosus. Critics of every school have long held that it is not safe to differ from Ptolemy. Some of his dates have received confirmation from modern astronomical calculations; and while, so far as I know, no tablets have yet been dug up by which his statements bearing on the period now under review can be checked, his figures belonging to other periods have been confirmed by a remarkable set of inscriptions found some years ago. We may therefore hold his list to be correct. It may interest some readers to see how the list proceeds, and how, by its help, we are brought into contact with Anno Domini. He begins with Nabonassar, and works downward, calling the first year of Nabonassar the Year One of his era. Nabopolassar, the father of Nebuchadnezzar, dies according to him in the year 143 of the era; then 144 counts as Nebuchadnezzar's first, I 86 as his last, and 187 as the first of Evil-Merodach. Halma, a mathematician and commentator on Ptolemy, says : 1 "The Ist of Thoth [New Year's Day] of the first Egyptian year of Nabonassar coincided in effect with the 26th of February 747 Julian before the Christian Era." Nebuchadnezzar's " accession year" is thus 605 B.C., his "first year" 604, his last (being the "accession year" of Evil-Merodach)

"Table Chronologique des Regnes, de C. Ptolímée, par M. L'Abbé Halma (Paris, I8Ig), Dissertation i., pp. 3, 4. 
$5^{62}$, and the "first year" of Evil-Merodach $5^{6} \mathrm{r} .{ }^{1}$ As has already been said, the statement of Ptolemy regarding the length of Nebuchadnezzar's reign confirms that of Berosus, and they both confirm the conclusion required by a comparison of the several passages of Scripture ; and now by the help of Ptolemy we have been enabled to fix the place of the dates under consideration in the chronology of the world.

The only passage in our English Bible bearing on the period, which will not agree with the rest of Scripture or with Ptolemy or Berosus, is Jer. lii. 3I, which says that "in the seven and thirtieth year of the captivity of Jehoiachin ... Evil-Merodach king of Babylon, in the first year of his reign, lifted up the head of Jehoiachin." That verse belongs to the Babylonian part of the book, and therefore its time must be interpreted after the Babylonian method. The "first year" of Evil-Merodach, then, as given by Ptolemy, is $56 x$, whereas the thirty-seventh of Jehoiachin's captivity, which coincided with the last year of Nebuchadnezzar, must have been 562 . But when we look again at our English Bible, we observe that the word "first" is in italics, showing it to be an interpolation of the translators. The clause should read " in the year of his reign," agreeing with 2 Kings xxv. 27, which says "in the year that he began to reign," and it will then harmonise with the rest of the Bible and with Berosus and Ptolemy.

It may not be superfluous to notice that it is Jehoiachin's captivity by which the years are computed. Had they been counted by his reign, the number would in a Babylonian passage have had to be entered as thirty-six, not thirty-seven.

Let us now gather up the facts we have discovered. They are these :-

(I) The first verse of the Book of Daniel, whose supposed inconsistency with Jeremiah and the historical Scriptures has been to many an evidence that the book is uninspired, and even caused some to doubt the prophet's historical existence, is, on the hypothesis of its Babylonian origin, in perfect harmony with those other writings, and that, not

\footnotetext{
${ }^{I}$ Unfortunatcly Ptolemy made no allowance for leap years, and therefore the beginning of his year shifts. His year I44 (the "first" of Nebuchadnezzar) would begin on our 2Ist of January. As that is not far from the beginning of the Babylonian and of the Jewish year, we may use it as practically synchronous with them.
}

after a strained interpretation, but when read in the meaning which any child would attach to the words.

(2) On the same hypothesis, the first verse of the second chapter of Daniel, whose supposed inconsistency with the first chapter has been another evidence against the book, likewise harmonises with it simply and completely.

(3) Those passages in Kings and Jeremiah making mention of captivities in the eighth and nineteenth years of Nebuchadnezzar, which were supposed to contradict other passages in the same books referring the same captivities to the seventh and eighteenth years, are, when read in the only reasonable way, confirmatory of them.

(4) The statement in Kings and Jeremiah regarding the time of the relaxation of Jehoiachin's captivity, which appeared to differ from the rest of the sacred narrative and from the works of Berosus and Ptolemy, is, when viewed in the light of the tablets, in perfect agreement with them. ${ }^{2}$

These facts have their bearing on the date and local source as well as the trustworthiness of the writings which have been considered. It would be wrong to draw conclusions from them which would be broader than the premises. There are many things in the Book of Daniel, e.g., that demand careful consideration before a satisfactory judgment can be arrived at; but the fact that certain matters, which have long been relied on with much assurance as telling against the book, turn out under fuller light to be wholly in its favour, will make the wise student proceed with greater caution before pronouncing adversely on the rest. And with regard to the general trustworthiness of the several books, we see how important are the different usus loquendi of the writers. We have not the same man telling the same thing in different ways at different times; but we have different witnesses who are not acquainted with each other's mode of speech giving their independent testimonies, and their evidence agrees throughout. And while the critics we have named have rendered great service to biblical investigation, we feel that here, in

"It need hardly be pointed out that this order brought out of the supposed confusion, where so many dates are involved, reflects back upon the principle of computation which has been employed, and proves its soundness. The lock and the key fit, and are of one workmanship. 
concluding certain dates to be "obviously false," or in coming forward to correct others with the view of making them tally, or in holding that in their general lines they are adaptcd, they are alike astray.

By far the most important service, however, that the Inscriptions have rendered in connexion with this period, lies in their having furnished a clue to the arrangement of the history. When dates which agree are assumed to be discrepant, it is manifest that not only will the chronology which is founded on them be at fault, but that the representation of the bearing which the events have upon each other will also be perverted. As might have been expected, there has been much divergence in the order in which the dates are arranged by different writers. When, on the other hand, we apply the principle of the different styles of Jewish and Babylonian computation to the original documents, the dates fall into a fixed line. The following table, I believe, will be found to satisfy all the scriptural statements :-
13.C.

Battle of Megiddo and death of Josiah, . . 609 Jehoahaz begins to reign, . . . . 609 Jehoahaz taken captive by Pharaoh-Necho, . 608 Jehoiakim set on throne by Pharaoh-Necho, . 608 Fall of Nineveh, . . . . . . ? 606 Battle of Carchemish, . . . . . 605 Jerusalem besieged and Jehoiakim taken by Nebuchadnezzar, . . . . . 605

Captivity of Danicl and others, . . . 605

Nebuchadnezzar succeeds to throne of Babylon: his first year according to Jewish reckoning,

His first year according to Babylonian reckoning, . . . . . . 604

Daniel interprets Nebuchadnezzar's dream, . 603

Death of Jehoiakim, . • • • 598

Jehoiachin begins to reign, and, along with Ezekiel, taken captive, - . $\quad$ - 598

Zedekiah set on throne by Nebuchadnezzar, . 597

Destruction of Jerusalem and deportation of Zedekiah and others, . $\quad . \quad$. 587

Further deportation, . . . . . 582

Death of Nebuchadnezzar and relaxation of Jehoiachin's captivity, • . • $\quad 562$

\section{Contributions and Commentr.}

\section{EBe Rimitation of our Rord's (Khnompledge.}

MARk xiii. 3I, 32.

This passage is generally adduced as proof of the limitation of our Lord's knowledge, even in regard to a matter so closely touching $\mathrm{His}$ special work and mission as the time of His Second Coning. And the inference is drawn: If ignorant then, how much more in regard to the authorship and dates of the books of the Old Testament! But whatever may be the nature of that limitation, which, in any case, was self-imposed and voluntary; however difficult the Catholic doctrine of the

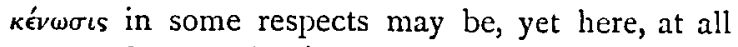
events, the premise is wrong, and so must be the conclusion drawn from it. Three facts in connexion with the passage in St. Mark have to be taken into account: First, The parallel passage in St. Matthew does not include "the Son" in the limitation in question; and the passage in St. Luke makes no limitation whatever, having nothing answering to the statement at all. This is highly significant and monitory, if Mark be taken here as the earliest of the Synoptists. It warns us that the expression there made was soon felt to be open to misunderstanding. And that some qualification is necessary will at once be obvious, when it is mentioned, secondly, that the disciples of our Lord, and indeed all the early Christians, and, presumably, "the angels," and, certainly, our Lord Himself, "the Son" did know the time of His Second Coming. The assertion is made over and over again in the Synoptics that His coming would be in that generation. The following references to one of them will suffice: Matt. x. 23, xvi. 28 , xxiv. 34 . In this faith the first generation of Christians, the contemporaries of our Lord and His disciples, lived and died. If in this faith they were not mistaken, if the prediction and hope was realised by them, then the emphasis in St. Mark's statement will fall upon the words, "of that day and hour": i.e., as we should say, upon the date in the calendar and the hour of the clock. It is of such definite chronological statement that 